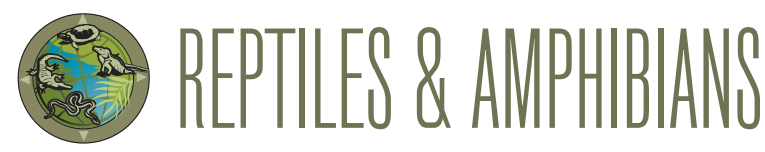

\title{
New Elevational and Locality Records and Notes on the Natural History of the Tamdil Leaf-litter Frog, Leptobrachella tamdil (Sengupta, Sailo, Lalremsanga, Das, and Das 2010) (Megophryidae), in Mizoram, India
}

\author{
Lal Muansanga ${ }^{1}$, Vanlal Siammawiii ${ }^{1}$, Gospel Zothanmawia $\operatorname{Hmar}^{1}$, F. Malsawmdawngliana ${ }^{1}$, Lal Biakzuala ${ }^{1}$, \\ Ht. Decemson ${ }^{1}$, Zothan Sangi ${ }^{2}$, and H.T. Lalremsanga ${ }^{1}$
}

${ }^{1}$ Developmental Biology and Herpetology Laboratory, Department of Zoology, Mizoram University, Tanhril, Aizawl, Mizoram, India (htlrsa@yahoo.co.in) ${ }^{2}$ Department of Zoology, Government Champhai College, Champhai, Mizoram, India

$\mathrm{T}$ he anuran family Megophryidae consists of 284 species that collectively range from Pakistan and western China, eastward to the Philippines and the Greater Sunda Islands (Frost 2021). Twenty-eight of these species occur in India (Dinesh 2020), ten of which are endemic to the northeastern part of the country (Saikia and Kharkongor 2017). The genus Leptobrachella Smith 1925 contains 86 currently recognized species, of which the Tamdil Leaf-litter Frog (L. tamdil) was described by Sengupta et al. (2010) on the basis of two specimens collected from the Tamdil National Wetlands, Saitual District, Mizoram, India. Vanlalsiammawii et al. (2020) reported an additional record from the Dampa Tiger Reserve, and Decemson et al. (2021) reported the occurrence of this species from Manipur, India.

We conducted Visual Encounter Surveys (VES) throughout Mizoram from February to May 2021 (Fig. 1), during which we collected 15 Tamdil Leaf-litter Frogs (nine males and six females) (Fig. 2) from the Sialring Stream, Dampa

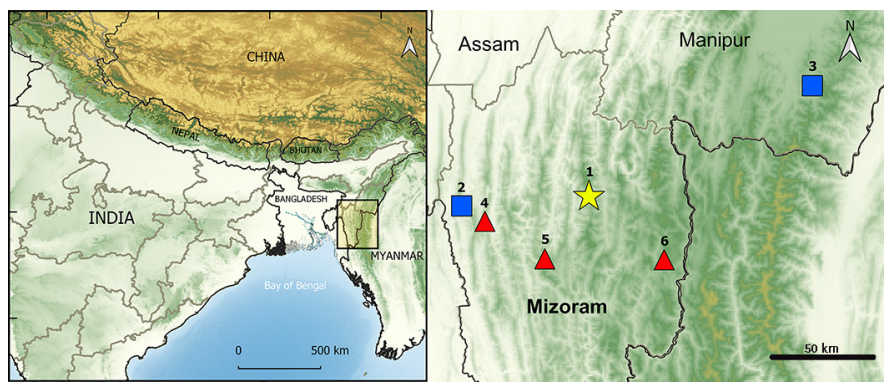

Fig. 1. Map showing the distribution of the Tamdil Leaf-litter Frog (Leptobrachella tamdil) in northeastern India. The type locality is indicated by the yellow star, published records are represented by blue squares, and the new records in Mizoram are marked by red triangles.

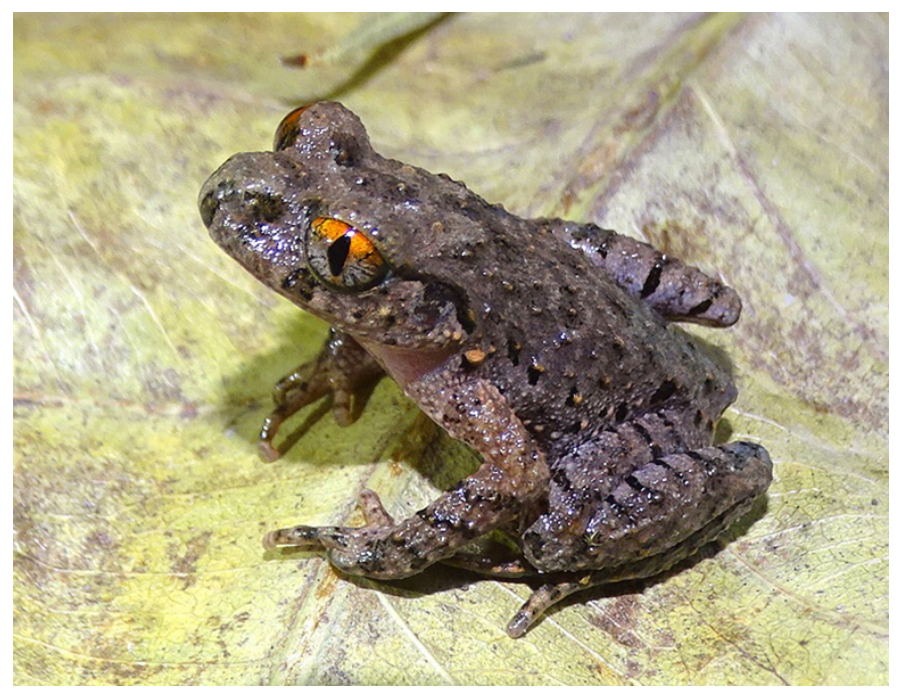

Fig. 2. A Tamdil Leaf-litter Frog (Leptobrachella tamdil) from Sihzau Stream, Zotlang, Champhai District, Mizoram, India. Photograph by H.T. Lalremsanga.

Tiger Reserve $\left(23.626572^{\circ} \mathrm{N}, 92.477578^{\circ} \mathrm{E} ; 518 \mathrm{~m}\right.$ asl), the Hmuifang Community Reserved Forest $\left(23.355006^{\circ} \mathrm{N}\right.$, $92.753772^{\circ} \mathrm{E} ; 1,458 \mathrm{~m}$ asl), and Zotlang, Champhai District $\left(23.449886^{\circ} \mathrm{N}, 93.303097^{\circ} \mathrm{E} ; 1,385 \mathrm{~m}\right.$ asl). Specimens were catalogued and fixed in $70 \%$ ethanol solution at the Departmental Museum of Zoology, Mizoram University (MZMU). Morphometric measurements (Table 1) follow Sengupta et al. (2010). Photographic vouchers were submitted to the Natural History Museum of Mizoram, Mizoram University, Aizawl, Mizoram, India (NHMM/G/2-4). The identity of all specimens collected was verified by Saibal Sengupta. 


\begin{tabular}{|c|c|c|c|c|c|c|c|c|c|c|c|c|c|c|c|}
\hline Museum no. & 2265 & 2266 & 739A & 739B & $739 \mathrm{C}$ & 739D & 739E & 2367A & 2367B & $2367 C$ & 2367D & 2367E & $2367 \mathrm{~F}$ & 2367G & 2367H \\
\hline Sex & M & M & $\mathrm{F}$ & $\mathrm{F}$ & $\mathrm{F}$ & $\mathrm{F}$ & M & $\mathrm{F}$ & M & M & $\mathrm{F}$ & M & M & M & M \\
\hline \multirow[t]{2}{*}{ Date of Collection } & \multicolumn{2}{|c|}{ 28.02.2021 } & \multicolumn{5}{|c|}{25.03 .2021} & & \multicolumn{7}{|c|}{25.04 .2021} \\
\hline & \multicolumn{2}{|c|}{ Hmuifang } & \multicolumn{5}{|c|}{ Dampa Tiger Reserve (Sialring Stream) } & & \multicolumn{7}{|c|}{ Zotlang, Champhai District } \\
\hline \multicolumn{16}{|c|}{ Measurements $(\mathrm{mm})$} \\
\hline SVL & 28.96 & 29.44 & 38.94 & 36.06 & 33.72 & 37.14 & 29.36 & 40.50 & 26.3 & 23.48 & 32.54 & 25.5 & 25.88 & 26.38 & 25.6 \\
\hline IN & 2.90 & 2.78 & 3.84 & 3.74 & 3.24 & 3.26 & 3.04 & 3.69 & 2.82 & 3.21 & 3.44 & 2.76 & 2.66 & 2.68 & 3.04 \\
\hline HL & 11.64 & 10.84 & 14.88 & 14.36 & 10.86 & 13.84 & 11.30 & 14.76 & 10.6 & 10.01 & 13.95 & 10.85 & 10.46 & 10.94 & 10.50 \\
\hline HW & 10.86 & 9.78 & 13.64 & 13.2 & 11.52 & 12.24 & 10.64 & 13.52 & 9.68 & 9.06 & 12.13 & 9.1 & 10.12 & 9.94 & 9.42 \\
\hline HD & 3.50 & 3.12 & 4.34 & 3.52 & 4.52 & 3.48 & 3.38 & 4.38 & 3.16 & 3.01 & 4.61 & 3.22 & 3.44 & 3.46 & 3.50 \\
\hline ED & 4.63 & 4.18 & 5.42 & 5.34 & 5.04 & 5.10 & 4.52 & 5.58 & 4.52 & 3.81 & 5.04 & 4.52 & 4.36 & 4.42 & 4.08 \\
\hline 10 & 3.10 & 3.32 & 3.72 & 3.74 & 4.31 & 3.56 & 3.05 & 3.68 & 3.12 & 3.36 & 3.54 & 3.18 & 3.34 & 3.16 & 2.84 \\
\hline E-S & 4.14 & 4.00 & 5.48 & 5.34 & 4.54 & 4.68 & 4.19 & 5.32 & 4.02 & 3.80 & 4.84 & 4.14 & 3.88 & 4.44 & 3.95 \\
\hline $\mathrm{E}-\mathrm{N}$ & 2.12 & 2.62 & 2.90 & 3.04 & 2.56 & 2.72 & 2.38 & 2.86 & 2.32 & 2.20 & 2.74 & 2.28 & 2.36 & 2.34 & 2.62 \\
\hline E-T & 1.12 & 1.04 & 1.68 & 1.58 & 1.28 & 1.36 & 1.28 & 1.62 & 1.06 & 1.14 & 1.46 & 1.30 & 1.32 & 1.23 & 1.26 \\
\hline UE & 3.23 & 2.84 & 4.38 & 3.58 & 3.06 & 4.38 & 3.04 & 4.20 & 2.68 & 3.10 & 3.71 & 2.68 & 2.58 & 2.89 & 2.60 \\
\hline HTD & 2.12 & 2.26 & 2.58 & 2.72 & 2.59 & 2.50 & 2.04 & 2.80 & 2.22 & 1.96 & 2.74 & 1.92 & 2.14 & 2.22 & 2.28 \\
\hline VTD & 2.12 & 2.08 & 2.58 & 2.60 & 2.46 & 2.50 & 1.94 & 2.72 & 2.20 & 1.94 & 2.72 & 2.00 & 2.16 & 2.30 & 1.74 \\
\hline $\mathbf{F L}$ & 7.28 & 7.32 & 10.42 & 10.72 & 8.65 & 8.96 & 7.48 & 11.17 & 7.68 & 6.68 & 8.34 & 6.78 & 7.17 & 7.06 & 6.68 \\
\hline TBL & 13.16 & 12.92 & 18.24 & 16.5 & 15.22 & 17.06 & 13.46 & 17.84 & 13.06 & 12.98 & 15.94 & 12.56 & 12.74 & 12.49 & 12.06 \\
\hline IMT & 1.78 & 1.50 & 2.02 & 1.86 & 1.53 & 1.94 & 1.30 & 1.52 & 1.52 & 1.09 & 1.92 & 1.70 & 1.66 & 2.08 & 1.94 \\
\hline IPT & 1.80 & 1.24 & 1.66 & 2.02 & 1.39 & 1.76 & 1.36 & 1.52 & 1.36 & 0.72 & 1.58 & 1.22 & 1.24 & 1.42 & 1.19 \\
\hline A-G & 14.24 & 13.94 & 16.72 & 17.26 & 13.52 & 17.9 & 13.7 & 18.92 & 11.56 & 11.02 & 14.34 & 10.98 & 10.88 & 11.78 & 11.08 \\
\hline BW & 10.41 & 10.08 & 14.88 & 12.40 & 10.12 & 10.66 & 9.88 & 11.90 & 10.54 & 9.13 & 9.82 & 8.92 & 9.15 & 10.80 & 10.21 \\
\hline
\end{tabular}

Table 1. Morphometric measurements of Tamdil Leaf-litter Frogs (Leptobrachella tamdi) from three new localities in Mizoram, India.

Individuals were quite abundant along the Sihzau Stream at Zotlang during the month of May, which probably is attributable to aggregation for breeding. Moreover, the presence of gravid females suggests that the breeding period is during the onset of the monsoon as per observations of Sengupta et al. (2010), Vanlalsiammawii et al. (2020), and Decemson

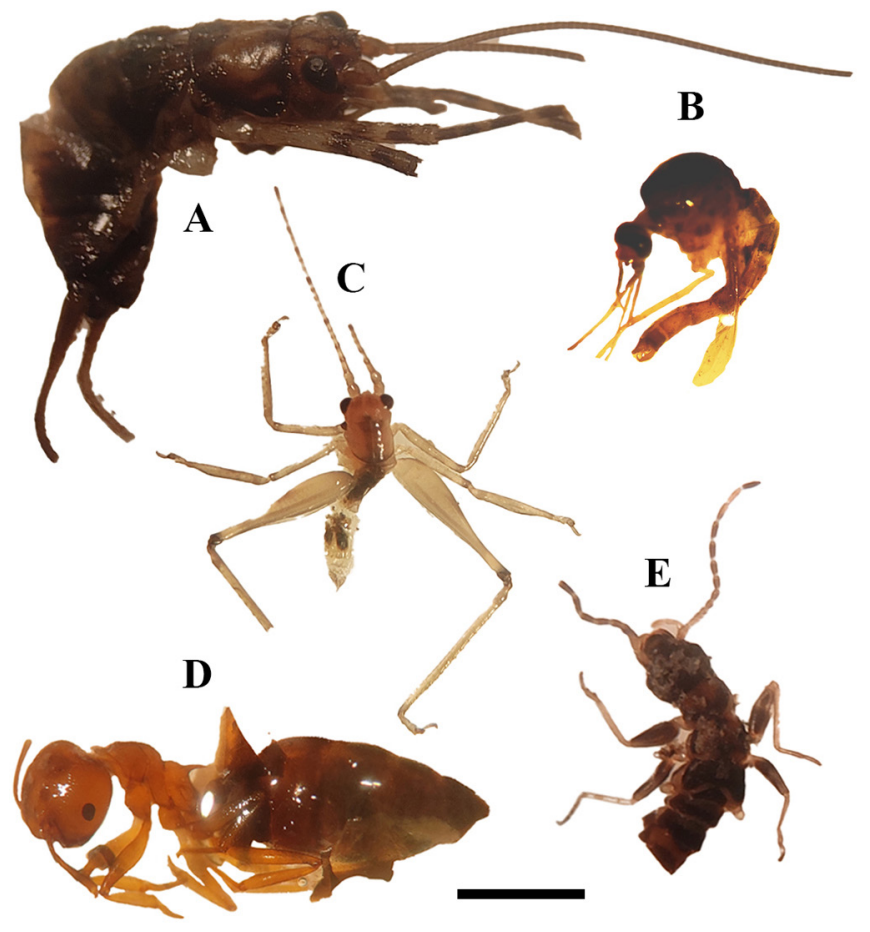

Fig. 3. Gut contents of a Tamdil Leaf-litter Frog (Leptobrachella tamdil) from Sihzau Stream, Zotlang, Champhai District, Mizoram, India: A. Orthoptera (katydid), B. Hemiptera, C. Orthoptera (cricket), D. Hymenoptera (ant), and E. Coleoptera (rove beetle). Scale bar $=3 \mathrm{~mm}$. Compiled and photographed by Lal Muansanga. et al. (2021). One gravid female from Zotlang, Champhai District (MZMU 2367A) (SVL $40.50 \mathrm{~mm}$ ), contained 187 eggs. Decemson et al. (2021) reported a female with 105 eggs, but that individual was smaller (SVL $33.2 \mathrm{~mm}$ ), which could explain the smaller clutch size (see also Gould et al. 2020). Gut contents of three specimens from Champhai (MZMU 2367C,D,F) included insects from four orders (Fig. 3). This is the first record of diet for this species.

The new localities documented herein represent the southernmost and highest elevational $(1,458 \mathrm{~m}$ asl $)$ records at the Hmuifang Community Reserved Forest, the westernmost record at Sialring, and the largest size (MZMU 2367A with SVL $40.50 \mathrm{~mm}$ ) recorded for the species. These new distributional records also suggest that the species is likely to occur in the adjacent states of Assam, Tripura, and Nagaland in northeastern India, and also in neighboring Bangladesh and Myanmar.

\section{Acknowledgements}

We thank Mr. Liandawla (Principal Chief Conservator of Forests), Government of Mizoram, for the permit (No.A.33011/2/99-CWLW/225) to collect herpetofauna in Mizoram; and the Defence Research Development Organisation (DRDO), Ministry of Defence (No. DFTM/07/3606/NESTC/ABR/M/P-01), and the Department of Biotechnology (DBT), Ministry of Science and Technology (No. DBT-NER/AAB/64/2017), Government of India, New Delhi, for financial support.

\section{Literature Cited}

Decemson, H., Vanlalsiammawii, L. Biakzuala, M. Vabeiryureilai, F. Malsawmdawngliana, and H.T. Lalremsanga. 2021. Occurrence of Tamdil Leaf-litter Frog Leptobrachella tamdil (Sengupta et al., 2010) (Amphibia: 
Megophryidae) from Manipur, India and its phylogenetic position. Journal of Threatened Taxa 13: 18624-18630. https://doi.org/10.11609/ jott.7250.13.6.18624-18630.

Dinesh, K.P., C. Radhakrishnan, B.H. Channakeshavamurthy, P. Deepak, and N.U. Kulkarni. 2020. A Checklist of Amphibians of India with IUCN Conservation Status. Version 3.0. Fauna of India Checklist, Zoological Survey of India, Kolkata, India. Available at: https://zsi.gov.in.

Frost, D.R. 2021. Amphibian Species of the World: An Online Reference. Version 6.1. American Museum of Natural History, New York, New York, USA. https:// doi.org/10.5531/db.vz.0001. <https://amphibiansoftheworld.amnh.org/>.

Gould, J., C. Beranek, J. Valdez, and M. Mahony. 2020. Quality versus quantity: The balance between egg and clutch size among Australian amphibians is related to life history and environmental conditions. bioRxiv. https://doi. org/10.1101/2020.03.15.992495.

Saikia, B. and I.J. Kharkongor. 2017. Checklist of endemic amphibians of Northeast India. Records of the Zoological Survey of India 117: 91-93. https:// doi.org/10.26515/rzsi/v117/i1/2017/117283.

Sengupta, S., S. Sailo, H.T. Lalremsanga, A. Das, and I. Das. 2010. A new species of Leptolalax (Anura: Megophryidae) from Mizoram, North-eastern India. Zootaxa 2406: 57-68. https://doi.org/10.11646/zootaxa.2406.1.3.

Vanlalsiammawii, Remruatpuii, V.L. Malsawmhriatzuali, Lalmuansanga, G.Z. Hmar, S. Sailo, H. Decemson, L. Biakzuala, and H.T. Lalremsanga. 2020. An additional record of the Tamdil Leaf-litter Frog Leptobrachella tamdil (Sengupta et al., 2010) (Amphibia: Megophryidae) from Dampa Tiger Reserve, Mizoram, India. Journal of Threatened Taxa 12: 15951-15954. https://doi.org/10.11609/jott.5999.12.8.15951-15954. 